\title{
An analytical study of some trace elements in water and plants using an atomic absorption spectrophotometer in Thi-Qar governorate
}

https://doi.org/10.32792/utq/uti/vol14/4/7

\author{
Asst. Prof. Dr. Sajid Hassan Guzar \\ Hawraa Chassib Bukhaibukh \\ College of science, chemistry department, \\ University of Thi-Qar \\ Emails: Sajid.h@uokerbala.edu.iq \\ hawraamaster99@gmail.com
}

\begin{abstract}
The present study was conducted to measure concentrations of six trace elements $(\mathrm{Cu}, \mathrm{Pb}, \mathrm{Zn}, \mathrm{Cr}, \mathrm{Ni}$ and $\mathrm{Cd})$ in water and plants (Apium graveolens , Lepidium sativum and Raphanus sativus). The samples were collected during winter 2016 from different places of Thi-Qar province. Levels of trace elements were determined by aflame atomic absorption spectroscopy (FAAS). The means concentrations of $\mathrm{Cu}, \mathrm{Pb}, \mathrm{Zn}, \mathrm{Cr}, \mathrm{Ni}$ and $\mathrm{Cd}$ in the water were 1.687, 3.052, 1.634, 4.082, 0.341 and 0.879 ppm respectively. In plants, their means concentrations in the A. graveolens plant were $3.288,1.930$, $2.850,3.440,0.375$ and $0.715 \mathrm{ppm}$ dry weight respectively, in the L. sativum plant were $(4.745,1.724,3.213,2.789,0.375,0.750)$ ppm dry weight respectively, and in the R. sativus plant were 4.677, 1.559, $2.348,2.483$, 0.373 and $0.679 \mathrm{ppm}$ dry weight respectively.It was found that most concentrations of trace elements in the water samples were exceeded the allowed limits for irrigation. Moreover, in A. graveolens, L. sativum and R. sativus plants, elements $\mathrm{Pb}, \mathrm{Cr}$ and $\mathrm{Cd}$ exceeded the allowed limits by Food and Agricultur organization (FAO) and World Health Organization (WHO).
\end{abstract}


Keyword s: trace elements , water, Apium graveolens , Lepidium sativum , Raphanus sativus ,Atomic absorption spectroscopy .

\section{Introduction1.}

The trace elements are dangerous environmental pollutants, it accumulate in the body of living organisms and it bio concentrated through their transition to different levels of the food chain to pass on to humans or other organisms at the end of food chain. It threat life and sometimes causing death [1]. Because it do not turn and do not decompose and also not affected by the sun when they exist in the environment. It can combine to form complexes and many other compounds [2]. Plants are one of the main links in the food chain and the trace elements affect significantly the effectiveness of the plant [3]. The plants have high sensitivity to the toxicity of trace elements and are effective as the first stage in the food chain works on the accumulation of pollutants in their textures compared with organism that are at higher food levels [4]. The increase in concentration of these elements in plants over permissible limits can put the consumer's life in danger [6.5] The reason of the concentrations increase of trace elements was attributed to irrigation water contaminated with sewage, household wastes and centesis water $[8,7]$, the concentration of trace elements in water was studied by many researchers [9,10,11, 12]. Ibrahim(2015) [13] investigated of concentrations $\mathrm{Cd}, \mathrm{Zn}, \mathrm{Pb}$, $\mathrm{Mn}, \mathrm{Ni}$ and $\mathrm{Cu}$ of Put up water from Baiji /the North refinery Company, this water used for irrigation purposes. His results showed trace element effect on celery plant and some other plants, that the water was led to a reduction in the percentage of germination and natural growth and high concentration of lead in celery, it exceeded the permitted limit..The concentrations of trace 
elements in A. graveolens, L. sativum and R. sativus plants were studied by many other researchers $[14,15]$. The objective of the present study was to measure concentrations of six trace elements $(\mathrm{Cu}, \mathrm{Pb}, \mathrm{Zn}, \mathrm{Cr}, \mathrm{Ni}$ and $\mathrm{Cd})$ in water and plants (A. graveolens, L.sativum and R.sativus) and assess water validity for irrigation and plants validity for human consumption by compare them with the allowed global limits.

\section{Materials and methods2}

\section{The Study station description2.1}

In the present study, four stations were selected in Thi-Qar province, these are:

Station 1 was located in Sdnawia area, water of this station receives polluted water directly from the sewage drainage station.

Station 2 was located in Al-Shawalish area in Suq al-Shuyukh, the water of this station was polluted by the sewage and human waste of people in this area..

Station 3 was located in five thousand area in Al Gharaf , also the water of this station was polluted with sewage and agricultural waste .

Station 4 was located in al-Shatrah District and surrounded by agricultural land.

The Stations were showed in Image 2-1 . 


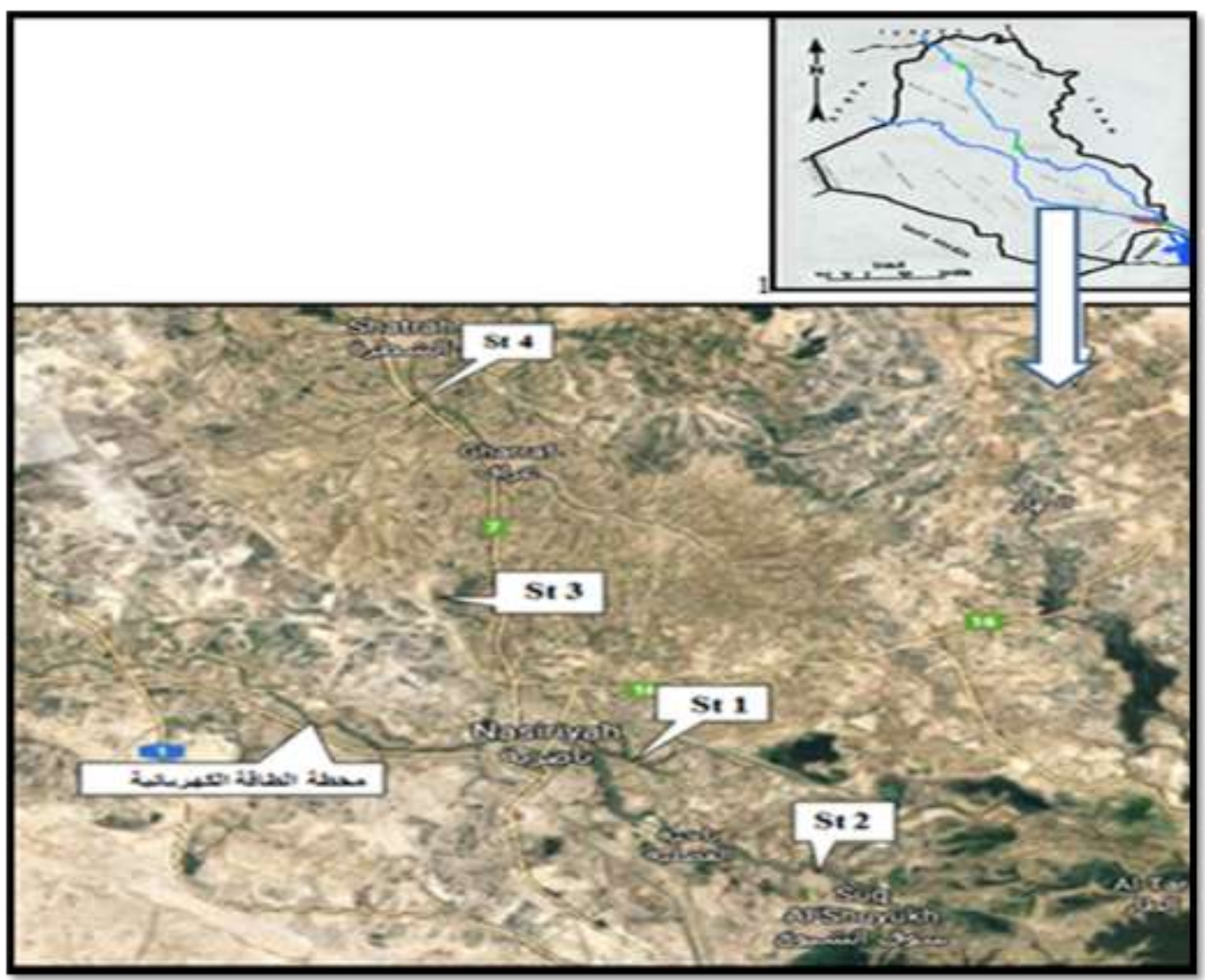

Image 2-1: Map showed the study stations

\section{Samples collection 2.2}

Samples of water and plants were collected from the study stations during winter 2016. 5 liters of water were taken at a depth $30 \mathrm{~cm}$ from each station were collected by using polyethylene bottles with a capacity $5 \mathrm{~L}$. The plant samples were collected from the same stations areas, then placed in plastic bags. All samples were transfered to the laboratory. 


\section{Extraction of Trace element2.3}

\section{.1 Extraction of trace elements in water2.3}

The water samples were digested using the method (APHA 1995). Firstly, 50 $\mathrm{ml}$ of a Water sample was transfered into a $100 \mathrm{ml}$ standard flask; then $5 \mathrm{ml}$ of concentrated Nitric acid was added. The sample was placed on a hot Plate Until it dried completely and white salt is appeared, finally, the white salt was dissolved with few drops of dilute hydrochloric acid $0.5 \mathrm{~N}$, and the solution transfered to a volumetric flask $(50 \mathrm{ml})$, the volume was completed to the mark with distilled water. The samples became ready to measure in atomic absorption spectrophotometric

The trace elements concentrations in water samples were determined by using flame atomic absorption spectrophotomer (PG-990).

\section{Extraction of trace elements in plants.3 . 2}

The plants were dried at the room temperature ; then grinded and sieved with 40 micron diameter sieve. Trace elements in plants were extracted according to the method of Barman et al., 2000. Firstly, $1 \mathrm{gm}$ of a plant samples were taken; then $5 \mathrm{ml}$ of the mixture of concentrated Nitric acid and concentrated Perchloric acid $(1: 4)$ were added, the mixture were left for 30 minutes. The mixture was placed on a hot plate until it become clear. Finally, the clear solution was filtered , transferred to a standard flask $(25 \mathrm{ml})$ and diluted to the mark with distilled water. The sample bcame ready to measure in atomic absorption spectrophotometric.

The trace elements concentrations in plant samples were determined by using flame atomic absorption spectrophotomer (PG-990). 


\section{4 Statistical analysis}

The results were analyzed statistically using the analysis of variance ( SPSS10 ), to find the values of standard deviation and correlation coefficient between trace element concentrations in water and plants

\section{. Result and Discussion3}

\section{.1 Trace elements in water3}

Table 3-1 and Figure 3-1 show the concentration of trace elements for the water samples.It can be observed from the table (3-1) and figure (3-1) that the trace elements concentrations in water can be arranged as follows: $\mathrm{Cr}>$ $\mathrm{Pb}>\mathrm{Cu}>\mathrm{Zn}>\mathrm{Cd}>\mathrm{Ni}$. The concentrations of $\mathrm{Cu}, \mathrm{Cr}, \mathrm{Ni}$ and $\mathrm{Cd}$ were exceeded the allowed limits for irrigation, while the means of $\mathrm{Zn}$ and $\mathrm{Pb}$ were within limits, the reason for the high concentration of trace elements in the water samples is the presence of many sources of polluted water such as waste and sewage water, and the use of agricultural fertilizers.Inaddition to the pesticides in agricultural areas adjacent to the water of the studied stations. This agrees with the results of [ 12,18,19]. The increase in the concentration of trace elements in this study water indicates to the danger using this water for irrigation.

Table 3-1: Concentrations of the trace elements in the water samples (ppm) 


\begin{tabular}{|l|l|l|l|l|l|l|}
\hline Station & Cu & Pb & Zn & Cr & Ni & Cd \\
\hline St 1 & 1.910 & 2.831 & 1.603 & 4.643 & 0.342 & 0.918 \\
\hline St 2 & 1.925 & 3.423 & 1.631 & 3.605 & 0.343 & 0.867 \\
\hline St 3 & 1.493 & 2.947 & 1.388 & 4.258 & 0.334 & 0.837 \\
\hline St 4 & 1.419 & 3.008 & 1.913 & 3.821 & 0.345 & 0.895 \\
\hline $\begin{array}{l}\text { Mean } \\
\text { 4tandard } \\
\text { deviation }\end{array}$ & 0.268 & 0.258 & 0.216 & 0.462 & 0.005 & 0.035 \\
\hline $\begin{array}{l}\text { The allowed } \\
\text { maximum } \\
\text { Limit [20] }\end{array}$ & 0.2 & 5 & 2 & 0.1 & 0.2 & 0.01 \\
\hline
\end{tabular}

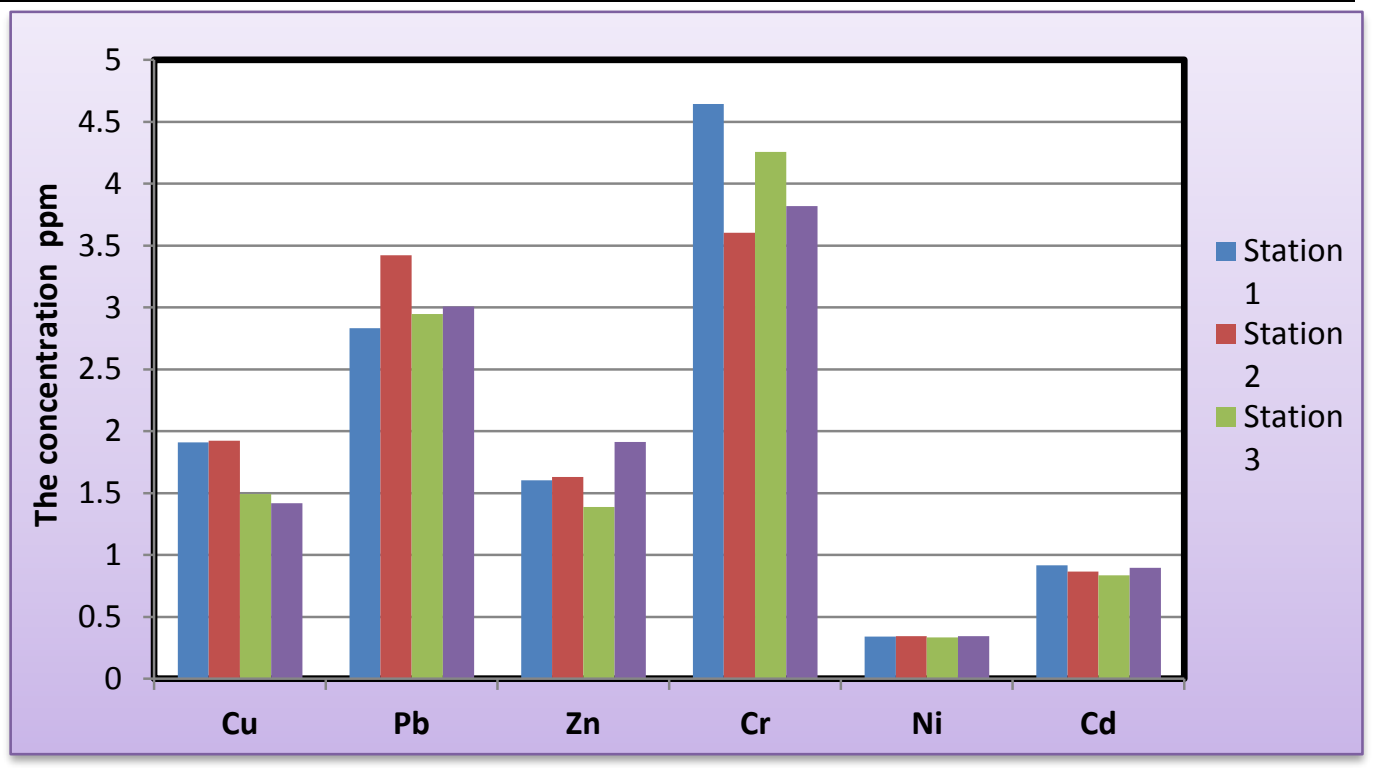

Figure 3-1: Concentrations of the trace elements in the water samples (ppm). 


\section{Trace elements in plants3.2}

Table 3- 2 and Figures 3-2 ,3-3, 3-4,3-5,3-6 and 3-7 show concentrations of trace elements in A. graveolens, L. sativum, and R. sativus plants It can be seen from the Table (3-2) and Figure (3-1) that the trace elements concentrations in $\mathrm{A}$. graveolens plant can be arranged as follows: $\mathrm{Cr}>\mathrm{Cu}>\mathrm{Zn}>\mathrm{Pb}>\mathrm{Cd}>$ $\mathrm{Ni}$, in L. sativum plant : $\mathrm{Cu}>\mathrm{Zn}>\mathrm{Cr}>\mathrm{Pb}>\mathrm{Cd}>\mathrm{Ni}$ and in R. sativus plant: $\mathrm{Cu}>\mathrm{Cr}>\mathrm{Zn}>\mathrm{Pb}>\mathrm{Cd}>\mathrm{Ni}$. The means of $\mathrm{Pb}, \mathrm{Zn}$ and $\mathrm{Cr}$ in the studied plants were exceeded the allowed limits of trace elements in vegetables but other elements within limits. The highest concentration of lead in A. graveolens plant is $1.930 \mathrm{ppm}$ while its concentration in L. sativum and R. sativus plants are 1.724 and $1.559 \mathrm{ppm}$ respectively.This indicate the high susceptibility of plants especially A. graveolens plant to obsorb this element even with its few concentrations in irrigation water .This is in agreement with result of [14]. The water polluted with waste should not be used to irrigate the A. graveolens plant for ability this plant on collect and store the elements in its different parts.Lead is a harmful element that moves from the plant to the consumer body of the human and animal through the food chain and does not contribute lead any vitality function of the body.Lead harms and affects in human health, it causes the red blood cells break and reduce the cognitive development and intellectual performance in children. It also causes heart and blood vessels diseases in adults [21]. The highest concentration of chromium in A. graveolens was $3.440 \mathrm{ppm}$ while this concentration in L. sativum and R. sativus plants were 2. 789 and 2. 483 ppm respectively. Chromium tripl eare important for human health but very small amounts. Recent studies show that chromium plays a key role in liberating insulin into the cell, as it is beneficial for diabetics and is essential for the metabolism of fat, carbohydrates and protein in the body [22]. The high concentration of chromium causes 
impaired immune system efficiency and change in genetic material and also causes lung cancer and death [23]. The highest concentration of Cadmium in L. sativum plant is $0.750 \mathrm{ppm}$ while its concentration in A. graveolens and R. sativus plants are 0.715 and $0.679 \mathrm{ppm}$ respectively. Cadmium is a highly toxic element and accumulates mainly in the kidneys and liver [24]. Cadmium promotes kidney failure, skeletal damage, and reproductive defects [25]. The high concentration of lead, chromium and cadmium elements in A. graveolens, L. sativum and R. sativus plants is back for irrigation their plants with pollutted water with these elements. This is confirmed by the statistical analysis of the correlation coefficient between lead, chromium and cadmium concentration in A. graveolens, L. sativum and R. sativus plants and their concentrations in water, positive correlation was found between the concentration of chromium in A. graveolens plant and its concentration in water $(r=0.173)$, positive correlation with cadmium ( $r=0.283)$ and positive correlation with lead element $(r=0.158)$ (Table 3-3). Also positive correlation was between concentrations Lead, chromium and cadmium in L. sativum plant and its concentrations in water $(r=0.368)$ for the lead element,$(r=0.404)$ for the chromium element and $(r=0.678)$ for the cadmium element (Table 3-4) ,positive correlation was found between lead, chromium and cadmium concentrations in $R$. sativus plant and its concentration in water $(r=0.034)$ for lead element, $(r=0.489)$ for the chromium element and $(r=0.845)$ for the cadmium element (Table 3-5).This agrees with the study [26].

Table 3- 2: Concentrations of the trace elements in the plants (ppm) dry weight (mean \pm standard deviation)

\begin{tabular}{|l|l|l|l|l|l|l|}
\hline The plant & $\mathbf{C u}$ & $\mathrm{Pb}$ & $\mathrm{Zn}$ & $\mathrm{Cr}$ & $\mathrm{Ni}$ & $\mathbf{C d}$ \\
\hline $\begin{array}{l}\text { A. } \\
\text { graveolens }\end{array}$ & $\begin{array}{l} \pm .288 \\
3.191\end{array}$ & \pm 0.464 & \pm 2.850 & \pm 1.016 & \pm 0.004 & $0.715 \pm 0.064$ \\
\hline
\end{tabular}




\begin{tabular}{|c|c|c|c|c|c|c|}
\hline L. sativum & $\begin{array}{l} \pm \quad 3.555 \\
4.745\end{array}$ & $\begin{array}{l} \pm \quad 0.339 \\
1.724\end{array}$ & $\begin{array}{l} \pm \quad 3.213 \\
1.225\end{array}$ & $\begin{array}{ll} \pm & 1.436 \\
2.789\end{array}$ & $\begin{array}{l} \pm \quad 0.006 \\
0.375\end{array}$ & $\begin{array}{l} \pm 0.031 \\
0.750\end{array}$ \\
\hline R. sativus & $\begin{array}{l} \pm \quad 4.175 \\
4.677\end{array}$ & $\begin{array}{l} \pm \quad 0.127 \\
1.559\end{array}$ & $\begin{array}{l} \pm \quad 2.348 \\
0.389\end{array}$ & $\begin{array}{ll} \pm & 0.783 \\
2 . & 483\end{array}$ & $\begin{array}{l} \pm 0.005 \\
0.373\end{array}$ & $\begin{array}{l} \pm 0.039 \\
0.679\end{array}$ \\
\hline $\begin{array}{l}\text { WHO/ } \\
\text { FAO } \\
{[27]}\end{array}$ & 73 & 0.3 & 100 & 2.3 & 67 & 0.2 \\
\hline
\end{tabular}

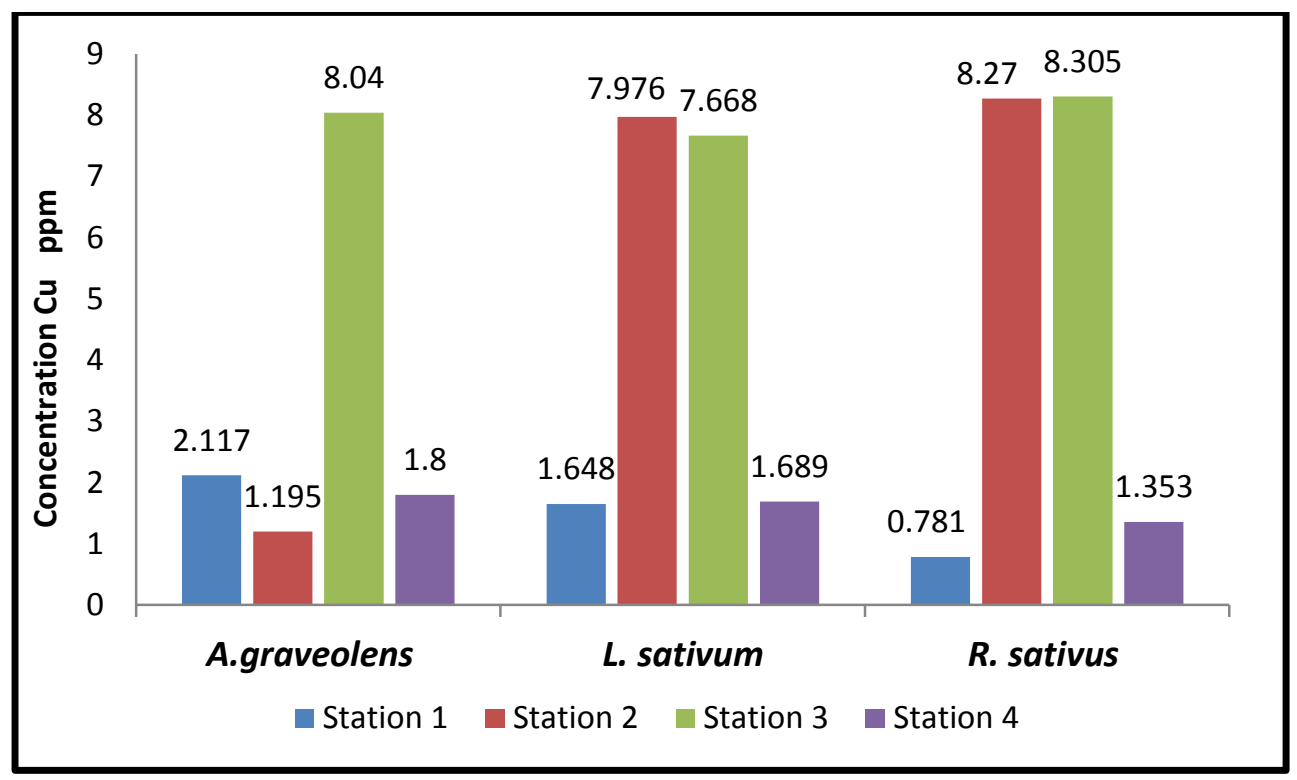

Figure 3-2: The concentration of copper in the plants (ppm) dry weight. 


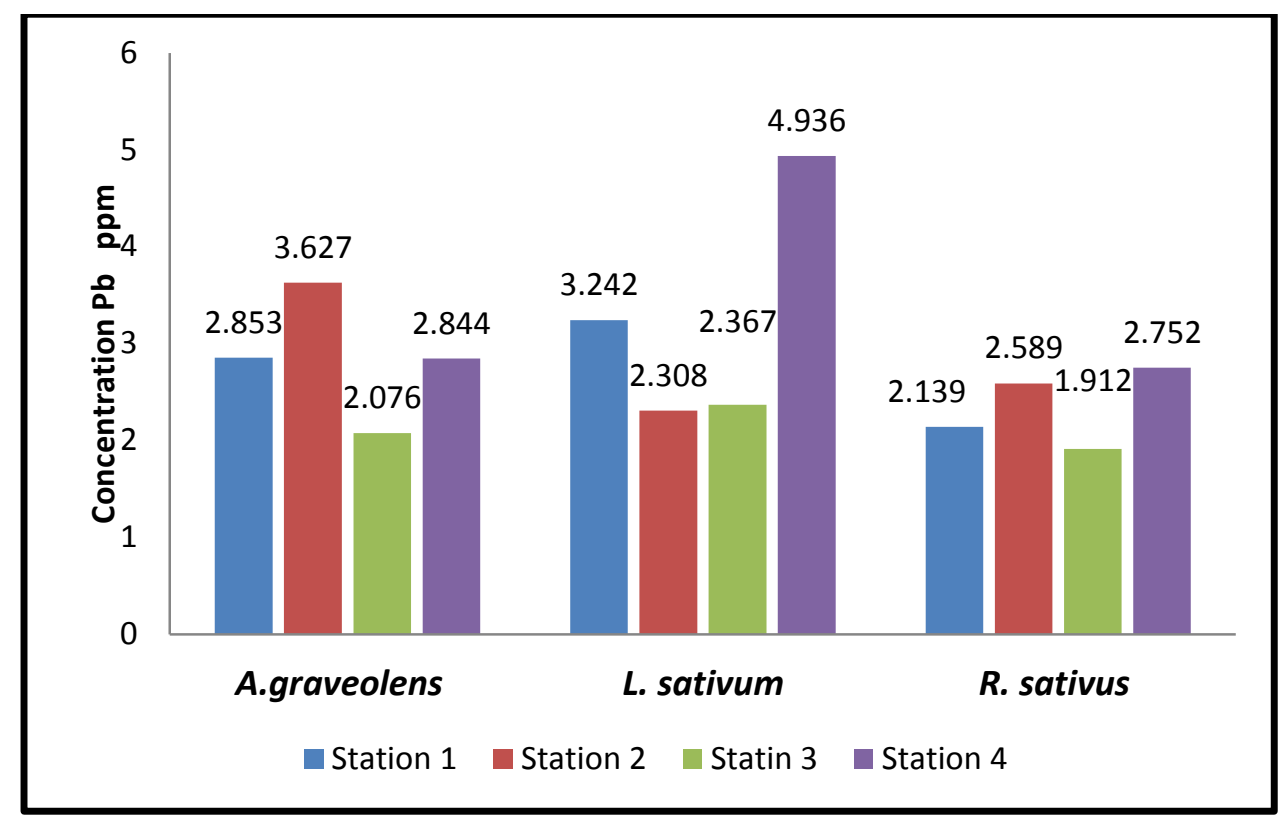

Figure 3-3: The concentration of lead in the plants (ppm) dry weight

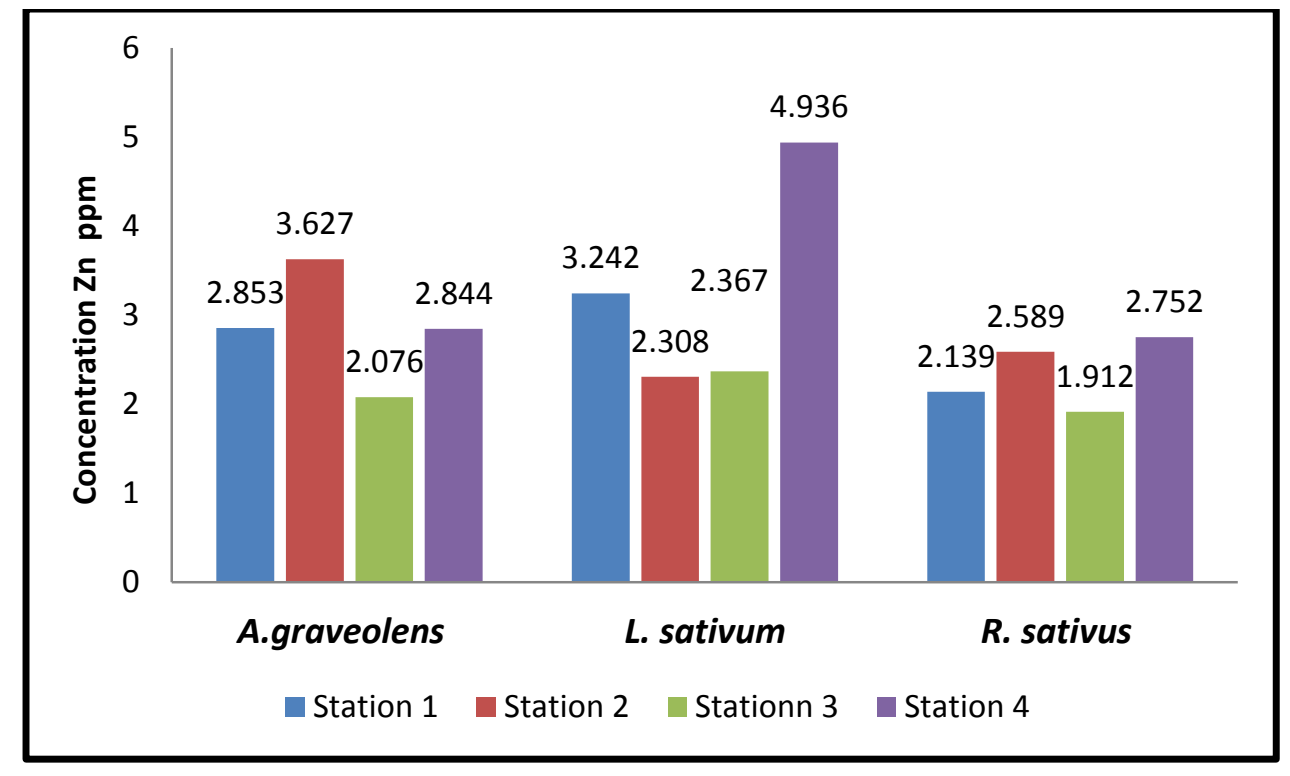

Figure 3-4 : The concentration of zinc in the plants (ppm) dry weight. 


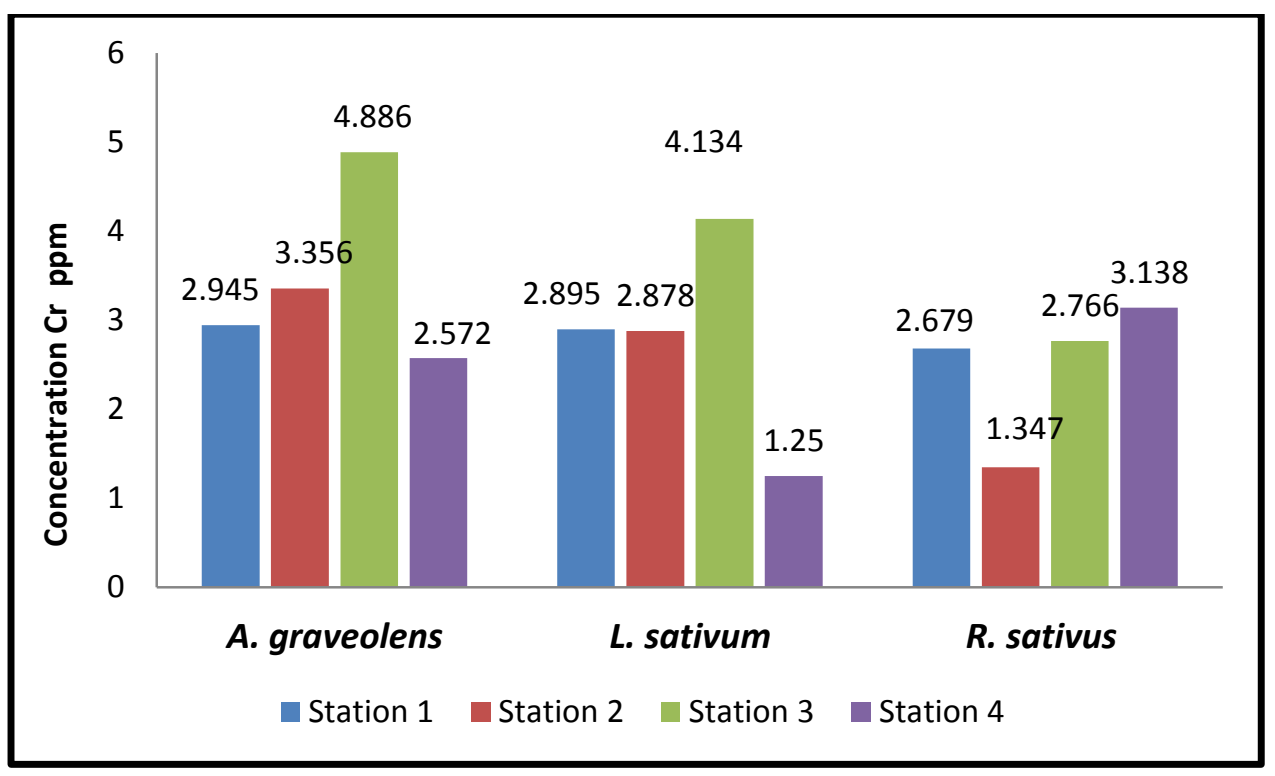

Figure 3-5: The concentration of chromium in the plants (ppm) dry weight.

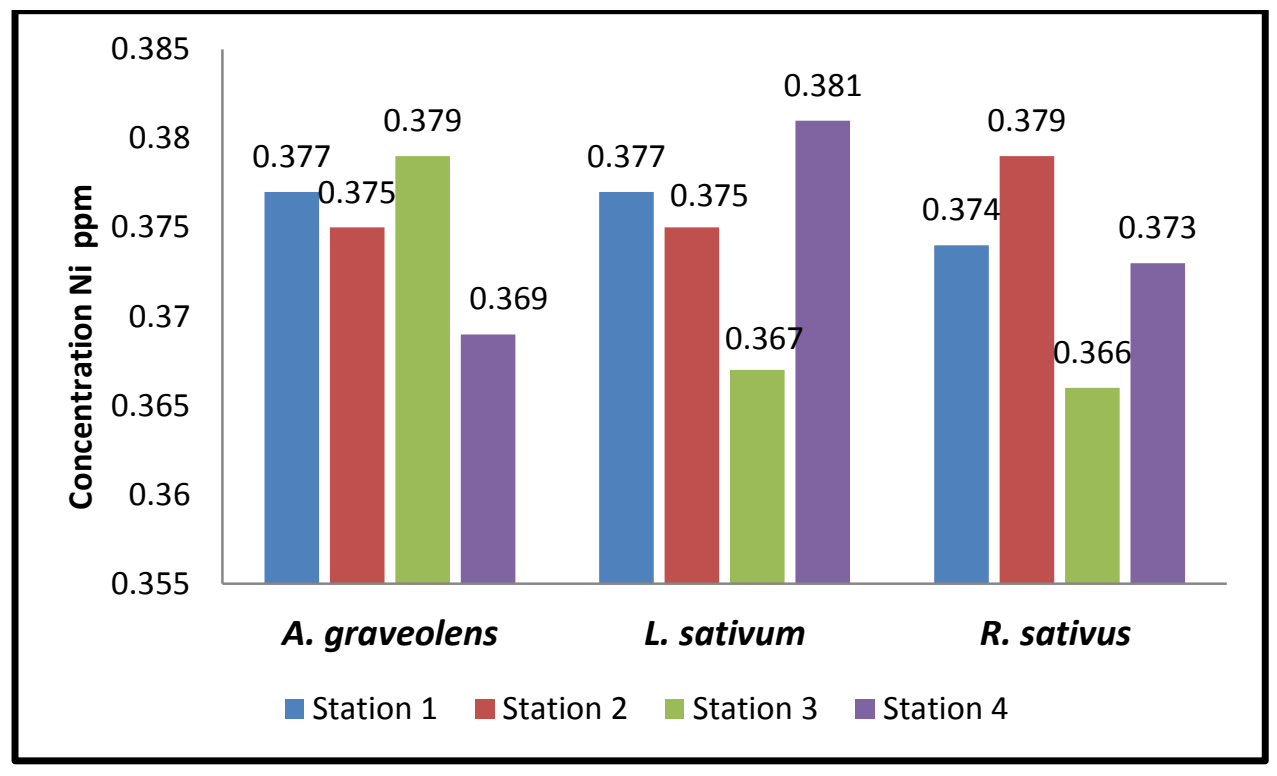

Figure 3-6: The concentration of nickel in the plants (ppm) dry weight. 


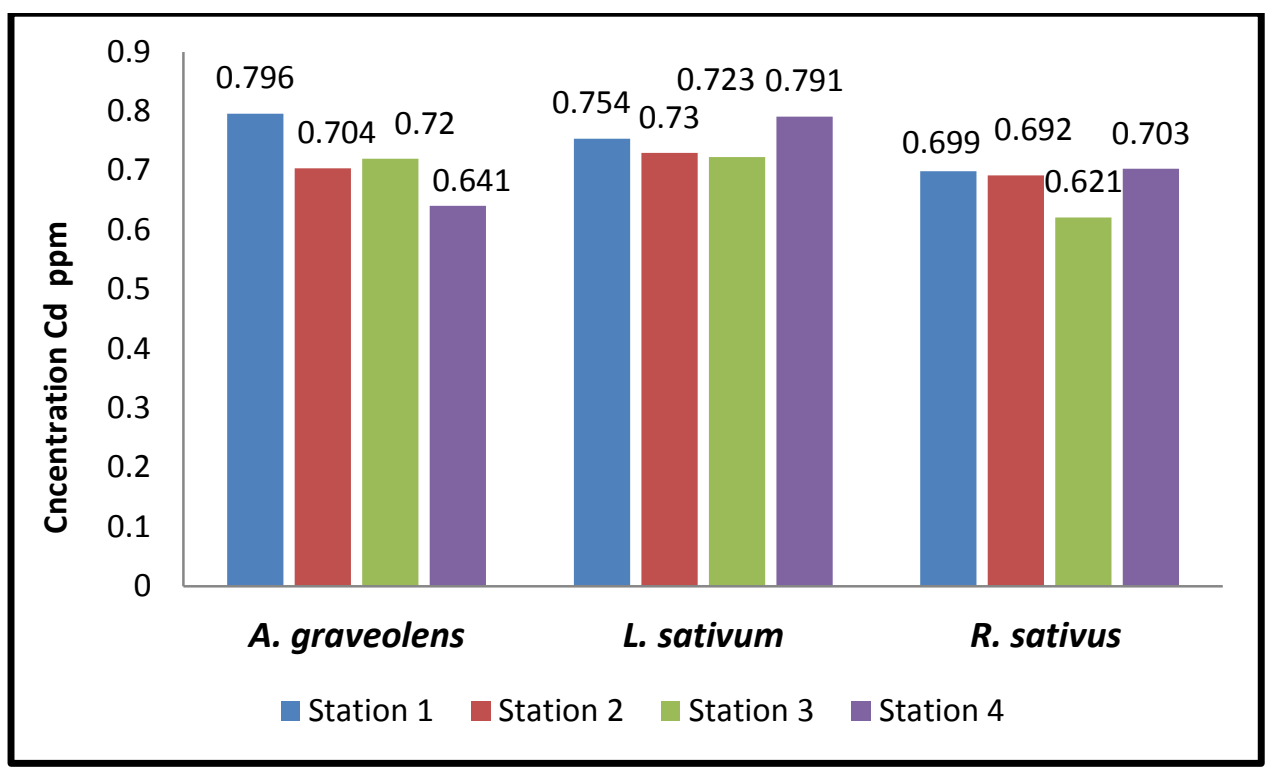

Figure 3- 7 : The concentration of cadmium in the plants (ppm) dry weight.

Table 3-3: The correlation coefficient between the trace elements in water and A. graveolens plant

\begin{tabular}{|c|c|c|c|c|c|c|c|}
\hline \multicolumn{8}{|c|}{ A . graveolens plant } \\
\hline \multirow{7}{*}{$\begin{array}{l}\text { The } \\
\text { water }\end{array}$} & Variables & $\mathbf{C u}$ & $\mathbf{P b}$ & $\mathbf{Z n}$ & $\mathrm{Cr}$ & $\mathbf{N i}$ & Cd \\
\hline & $\mathbf{C u}$ & -0.499 & 0.536 & 0.662 & -0.218 & 0.368 & 0.669 \\
\hline & $\mathbf{P b}$ & -0.385 & 0.158 & 0.754 & -0.045 & -0.179 & -0.391 \\
\hline & $\mathbf{Z n}$ & -0.747 & -0.910 & 0.455 & -0.887 & -0.974 & -0.591 \\
\hline & $\mathrm{Cr}$ & 0.354 & 0.599 & -0.573 & 0.173 & 0.566 & 0.802 \\
\hline & $\mathbf{N i}$ & -0.964 & -0.661 & 0.758 & -0.968 & -0.799 & -0.295 \\
\hline & Cd & -0.727 & -0.245 & 0.349 & -0.870 & -0.409 & 0.283 \\
\hline
\end{tabular}

Table 3- 4 : The correlation coefficient between the trace elements in water and L. sativum plant

\begin{tabular}{|c|c|c|c|c|c|c|}
\hline \multicolumn{7}{|l|}{ L. sativum plant } \\
\hline Variables & $\mathbf{C u}$ & $\mathbf{P b}$ & Zn & $\mathrm{Cr}$ & $\mathbf{N i}$ & Cd \\
\hline $\mathrm{Cu}$ & 0.115 & 0.832 & -0.514 & 0.353 & 0.082 & -0.390 \\
\hline $\mathbf{P b}$ & 0.622 & 0.368 & -0.347 & -0.016 & 0.029 & -0.306 \\
\hline
\end{tabular}




\begin{tabular}{|l|l|l|l|l|l|l|l|}
\hline \multirow{3}{*}{$\begin{array}{l}\text { The } \\
\text { water }\end{array}$} & $\mathbf{Z n}$ & -0.646 & -0.675 & 0.872 & -0.986 & 0.940 & 0.908 \\
\cline { 2 - 8 } & $\mathbf{C r}$ & -0.399 & 0.151 & -0.089 & 0.404 & -0.227 & -0.086 \\
\cline { 2 - 8 } & $\mathbf{N i}$ & -0.569 & -0.287 & 0.621 & -0.814 & 0.961 & 0.713 \\
\cline { 2 - 8 } & $\mathbf{C d}$ & -0.886 & -0.194 & 0.583 & -0.545 & 0.824 & 0.678 \\
\hline
\end{tabular}

Table 3- 5 : The correlation coefficient between the trace elements in water and R. sativus plant

\begin{tabular}{|c|c|c|c|c|c|c|c|}
\hline \multicolumn{8}{|c|}{ R. sativus plant } \\
\hline \multirow{7}{*}{$\begin{array}{l}\text { The } \\
\text { water }\end{array}$} & Variables & $\mathbf{C u}$ & $\mathbf{P b}$ & Zn & $\mathrm{Cr}$ & $\mathbf{N i}$ & Cd \\
\hline & $\mathrm{Cu}$ & 0.052 & -0.779 & -0.041 & -0.726 & 0.698 & 0.397 \\
\hline & $\mathbf{P b}$ & 0.607 & 0.034 & 0.543 & -0.864 & 0.662 & 0.181 \\
\hline & $\mathbf{Z n}$ & -0.633 & 0.736 & 0.896 & 0.218 & 0.483 & 0.810 \\
\hline & $\mathrm{Cr}$ & -0.413 & -0.536 & -0.767 & 0.489 & -0.476 & -0.213 \\
\hline & $\mathbf{N i}$ & -0.585 & 0.380 & 0.875 & -0.127 & 0.799 & 0.975 \\
\hline & Cd & -0.913 & 0.005 & 0.335 & 0.241 & 0.464 & 0.845 \\
\hline
\end{tabular}

\section{Conclusion .4}

1-The concentrations of $\mathrm{Cu}, \mathrm{Cr}, \mathrm{Ni}$ and $\mathrm{Cd}$ in water were exceeded the allowed limits for irrigation, this indicates to this water is not suitable for irrigation. The order of trace elements concentrations in water $\mathrm{Cr}>\mathrm{Pb}>\mathrm{Cu}>$ $\mathrm{Zn}>\mathrm{Cd}>\mathrm{Ni}$.

2-The concentrations $\mathrm{Pb}, \mathrm{Cr}$ and $\mathrm{Cd}$ in plants (A. graveolens , L. sativum and R. sativus) were exceeded the allowed limits of trace elements in vegetables but other elements within the allowed limits.

3- The order of trace elements concentrations in A. graveolens plant $\mathrm{Cr}>\mathrm{Cu}>$ $\mathrm{Zn}>\mathrm{Pb}>\mathrm{Cd}>\mathrm{Ni}$, in L. sativum plant $\mathrm{Cu}>\mathrm{Zn}>\mathrm{Cr}>\mathrm{Pb}>\mathrm{Cd}>\mathrm{Ni}$ and in R. sativus plant $\mathrm{Cu}>\mathrm{Cr}>\mathrm{Zn}>\mathrm{Pb}>\mathrm{Cd}>\mathrm{Ni}$.

4- The high concentration of $\mathrm{Pb}, \mathrm{Cr}$ and $\mathrm{Cd}$ in the plants is due to irrigation this plants with pollutted water with these elements. This is asserted by the statistical analysis of the correlation coefficient between $\mathrm{Pb}, \mathrm{Cr}$ and $\mathrm{Cd}$ concentrations in the plants and their concentrations in water . 


\section{References}

1- Agah , H.; Leermakers, M.; Fatemi, S. M. R. and Baeyens, W. (2009). Accumulation of trace metals in the muscles and liver tissues of five fish species from the Persian Gulf.Environ. Monit.Assess. 157: 499- 514.

2- Uzun , I . and Guzel , F. (2000) . Adsorption of some heavy metal ions from aqueous solution by Activated carbon and comparison of precent adsorption results of activated carbon with those of some other adsorbents . Turk. J. Chem. 24: 291-297.

3- Veselov,D.;Kudoyarova,G;Symonyan,M.and Veselov,S.(2003). Effect of $\mathrm{Cd}$ on ion up take,Transpiration and cytokinin.contenet in wheat seedlings.J Bulg plant physiol. 353-359 .

4-Lovett-Doust, J. ; Schmidt, M. and Lovett- Doust, L. (1994).Biological assessment of aquatic pollution .areview with emphasis on plants as biomonitors Biol, Rev. 69:147-186.

5-Anonymous. (1998). Health Guide Line For The Use Of Waste Water in Agricalture and Aquacult-ure. Report of WHO Science Group. WHO. Geneva, Switzerla. Tech. Rep. Sci. 778, 10.

6-Codex Alimentarins Commission (FAO/WHO). (2001). Food Additives and Contaminats ,Joint FAO/WHO Food Standards Program. ALLNORM 01/12A. 1-289.

7 -Sadek, A. H and Kamel, K. F.(2008).Monthly Variations in Concentrations of Trace elements of Waters from Al-Garaf, one of the Main Branches of Tigris Rivere. partment of Fisheries and Marine Resources.College of Agriculture, University of Basrah. 
8-AZita, B. H. and Seid, A. M. (2008). Investigation of heavy metals up take by vegetable crops from metal - contaminated soil. Warld Academy of Sciece, Engineering and Technology. 43(1): 56-58.

9 -Alkam, F.M.(2002). Concentration of some trace elements in the water and plants of the Diwaniyah River - Al Gharraf - Al Qadisiyah journal - Pure Sciences. 7 (4): 190- 196.

10- Salman, J.M. (2006). Environmental study of potential pollution in the Euphrates River between the Indian Lake and the Kufa .Doctorate thesis, Iraq, College of of Science, University of Babylon.

11- Bushra, A. G. (2013). The Effect of Sewage water Treatment in Some Physical, Chemical and Bacteriological of Euphrates River Near the City Center of Nasiriyah, Southern Iraq.Master Thesis, College of Science, Dhi Qar University.

12- Afaq, T.F. (2012) .Study of the effect of Thermal energy of power plant effluents upon the concentration of some trace elements in water, sediment and two aquatic plants species in Euphrates River near the center of Al-Nassyria city south Iraq. Master Thesis, College of Science, Dhi Qar University.

13-Mariam,A.A. (2015). Evaluation Pollution in the soil and some vegetative plants with the trace elements located on the water table corridor resulting from the Baiji refinery. Journal University of Kirkuk - scientific studies. 160: 10-176.

14- Asen, H.A.; Ibrahim,O.S.; Jihad, T.M. (2015). A study of the effect of treated wastewater by sedimentation and filtration methods in the accumulation of trace elements in celery plants. Journal of the University of Kirkuk, scientific studies. 10: 58-71. 
15- Ghufran, F.J.; Riad , H.A. (2010). Evaluation of Pollution of Heavy Elements in Agricultural Land in Diyala Bridge. Department of Construction and Construction , University of Technology . Iraqi Journal of Market Research and Consumer Protection. 2 (3).

\section{6-ROPME (Regional Organization For the Protection of the Marine} Environment) (1983). Manual of oceanographic observation and pollutants analysis methods. AL - Safat, Kuwait. ROPME, P.O. Box 26388, 13124.

17-Thomas(2007). O. Burgess C. UV-Visible spectrophotometry of water and wastewater. Elsevier B.V. Netherlands.

18- Raed,S.A. (2004). Water characteristics in the Shatt al-Arab and the general estuary and their levels of pollution with some heavy elements. Doctorate thesis, College of Agriculture, University of Basra.

19- Alia, H. T. (2012). An environmental study of L. Ceratophyllum demersum. and its role in removing cadmium from the water of the river Euphrates in the city of Nazareth. Master thesis, College of Education, Dhi Qar University.

20-Ayers, R. S., and D. W. Westcot.( 1985). "Water Quality for Agriculture." Irrigation and Drainage Paper no. 29, Rev. 1. Rome: Food and Agriculture Organization

21-Mahalakshmi, M.; Balakrishnan,S.; Indira,K. and Srinivasan, M. (2012). Characteristic levels of heavy metals in canned tuna fish. Journal of Toxicology and Environmental Health Sciences. 4(2): 43-45.

22-Schauss,A.G.(1994).Minerals and human health.The relation for optimal and balanced elementtracelevels.Nut.Rev.,52:367-375. 
23-Ahmed ,I.T. and Abd Almoneim. (2012). Heavy elements sources and damage to the environment. Center for promising research in biological control and agricultural information, Qassim University .

24-Duruibe, J.O. ; Ogwuebu, M.O.C. and Egwurugwu, J.N. (2007). Heavy metal pollution and human biotoxic effects. Internat.J .Phys.Sci.2(5):112-118.

25-Rahimi, E.; Hajisalehi, M.; Kazemeini, H. R.; Chakeri, A.; Khodabakhsh, A.; Derakhshesh, M.; Mirdamadi, M.; Ebadi, A. G.; Rezvani, S. A, and Kashkahi, M. F. (2010). Analysis and determination of mercury, cadmium and lead in canned tuna fish marketed in Iran. African Journal of Biotechnology. 9 (31): 4938-4941

26-Durdana, R. H.; Shahnaz, I. and Shaikh, G. H. (2007). Assessment of the level of trace metal in commonly edible vegtables locally available in themaret of Karachi city .Pak.J.Bot.39(3) : 747-751.

27-Anonymous. 2001. Codex Alimentarius Commission (FAO/WHO). Food additives and contaminants-Joint FAO/WHO Food Standards Programme. 2001,ALINORM 01/12A. 1-289. 
دراسة تحليلية لبعض العناصر النزرة في الماء والنباتات باستخدام مطيافية الامتصاص الذري في محافظة ذي قار في الفاء

حوراء جاسب بخيخ

ا.م.د.ساجد حسن كزار

الخلاصة : الجر

اجريت الدراسة الحالية لتقدير تراكيز ستة من العناصر النزرة (النحاس , الرصاص, الخارصين ,

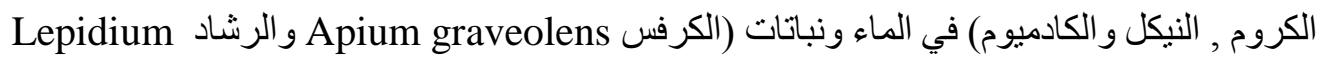

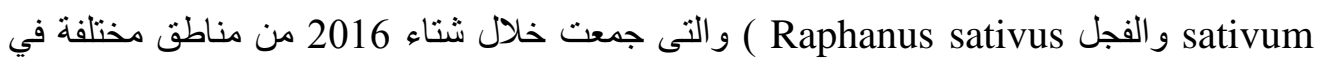
محافظة ذي قار واستخدم جهاز مطياف الامنصاص الذري اللهبي في تقدير تراكيز العناصر المدروسة . بلغت معدلات نراكيز العناصر (النحاس , الرصاص , الخارصين , الكروم, النيكل

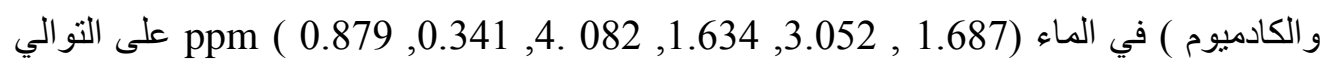

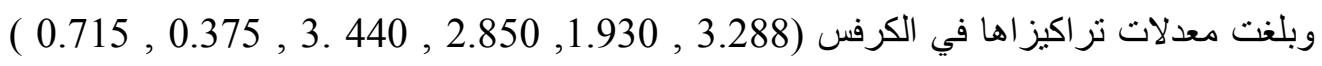

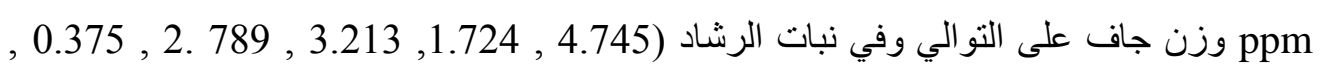

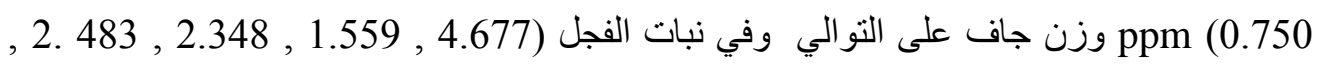

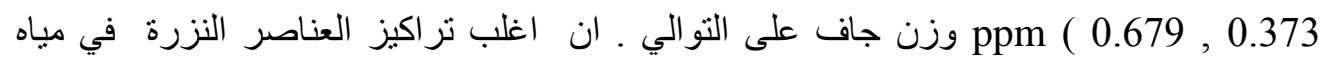

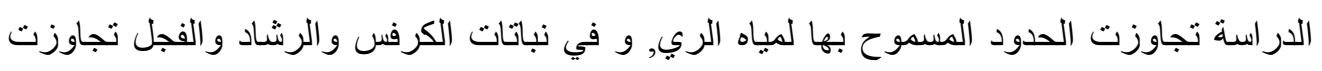

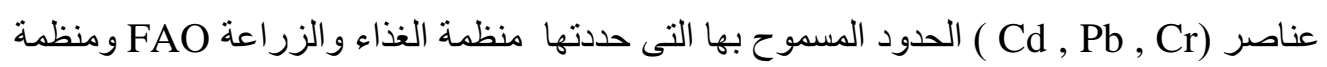

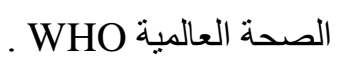

الكلمات المفتاحية : العناصر النزرة , الماء, الكرفس, الرشاد , الفجل, مطبافية الامنصاص الذري. 